\title{
Analisis Kandungan Nutrisi Dedak Padi sebagai Pakan Ternak dan Pendapatan Usaha Penggilingan Padi di Umalulu, Kabupaten Sumba Timur
}

\author{
(Analysis of Nutritional Content of Rice Bran as Animal Feed and Income of Rice Milling Business \\ in Umalulu, East Sumba Regency) \\ Jintonius Rihi Mila ${ }^{1 *}$, I Made Adi Sudarma ${ }^{1}$ \\ ${ }^{1}$ Fakultas Sains dan Teknologi, Jurusan Peternakan Universitas Kristen Wira Wacana Sumba Jjl. R. Soeprapto No.35, \\ Waingapu-Nusa Tenggara Timur \\ * Penulis Korespondensi : umbujtr230198gmail.com
}

Dikirim (received): 02 Oktober 2021; dinyatakan diterima (accepted): 27 Oktober 2021; terbit (published): 15 November 2021. Artikel ini dipublikasi secara daring pada https://ejournal.unib.ac.id/index.php/buletin_pt/index

\begin{abstract}
Rice bran is a feed ingredient for livestock, where this type of feed is easy to find, the price is relatively cheap, and has sufficient nutritional content. However, sometimes the nutritional content of the bran begins to be doubted because there is a tendency for high crude fiber. This study aims to determine the nutritional content of rice bran which is used as animal feed and to analyze the income of the rice milling business. Respondents taken were 14 owners of rice milling businesses. This research was done in Umalulu District, East Sumba Regency from July to August 2021. The method used in this research was descriptive quantitative. The sample was carried out by census and for the analysis of the nutritional content of the bran using stratified random sampling (random) with the number of samples analyzed as many as 6 samples. Nutritional content of rice bran was determined using proximate analysis at the Undana Kupang Feed Chemistry Laboratory, NTT. The average income of rice milling business was calculated using MS Excel application. It was shown that the income from the rice milling business in Umalulu District was Rp. 78.992.004 per year. The average nutritional content of rice bran without husk was $90.741 \%$ dry matter, $9.163 \%$ crude protein, and $15.414 \%$ crude fiber. The average nutritional content of rice bran containing husks was $89.836 \%$ dry matter, $9.831 \%$ crude protein, and $14.717 \%$ crude fiber. Thus, none of the rice bran produced in Umalulu District meets feed quality standards.
\end{abstract}

Key words: nutritional content of rice bran, rice milling business income, Umalulu

\section{ABSTRAK}

Dedak padi merupakan bahan pakan untuk ternak, dimana jenis pakan ini mudah ditemukan, harga relatif murah, dan memiliki kandungan nutrisi yang cukup. Namun terkadang kandungan nutrisi dedak mulai diragukan karena ada kecenderungan serat kasar yang tinggi. Penelitian ini bertujuan untuk mengetahui kandungan nutrisi dedak padi yang dijadikan sebagai pakan ternak dan analisis pendapatan usaha penggilingan padi. Responden yang diambil berjumlah 14 pemilik usaha penggilingan padi. Penelitian ini dilaksanakan di Kecamatan Umalulu Kabupaten Sumba Timur mulai dari bulan Juli sampai bulan Agustus di tahun 2021. Metode yang digunakan dalam penelitian ini adalah deskriptif kuantitatif. Penentuan sampel dilakukan secara sensus dan untuk analisis kandungan nutrisi dedak menggunakan stratifikasi random sampling (acak) dengan sampel sebanyak 6 sampel. Analisis kandungan nutrisi dedak padi menggunakan analisis proksimat. Analisis data untuk menghitung rata-rata pendapatan usaha penggilingan padi menggunakan aplikasi MS Excel. Sementara rata-rata kandungan nutrisi dedak padi yang mengandung sekam adalah bahan kering $89,836 \%$, protein kasar $9,831 \%$, dan serat kasar $14,717 \%$. Jadi, dedak padi yang dihasilkan di Kecamatan Umalulu tidak ada yang memenuhi standar mutu pakan.

Kata kunci: kandungan nutrisi dedak padi, pendapatan usaha penggilingan padi, Umalulu 


\section{PENDAHULUAN}

Dedak padi adalah hasil luaran dari olahan padi menjadi beras, dimana kualitas dedak padi akan bermacam-macam tergantung dari jenis padi. Dedak padi merupakan salah satu hasil pada pabrik penggilingan padi dalam memproduksi beras (Superianto et al. (2018). Dedak padi juga biasa digunakan dalam penyusunan ransum ternak. Menurut Munandar et al. (2020) bahwa ransum adalah gabungan pakan ternak yang sudah diramu dan secara umum terdiri dari beberapa jenis bahan pakan dengan takaran tertentu. Menurut Valentino et al. (2017) bahwa dedak padi dapat digunakan untuk bahan pakan ternak. Dalam penggunaan dedak padi ditemukan ada indikasi tentang penurunan kandungan nutrisi dedak halus di Kabupaten Sumba Timur sesuai dalam penelitian Dapawole dan Sudarma (2020) yang menyatakan bahwa komposisi nutrisi dedak halus yang ada di kabupaten Sumba Timur mengalami penurunan kualitas. Dedak padi di Kabupaten Sumba Timur mengandung 88,928 \% BK, 74,095 \% BO, 5,386\% PK, 2,797 \% LK, dan $26,431 \%$ SK. Jadi, serat kasar dari dedak padi sangat tinggi dan kandungan protein yang rendah. Kandungan nutrisi dedak padi bervariasi. Hal itu disebabkan karena ada penggilingan padi yang mengeluarkan sekam dan ada penggilingan padi yang mencampurkan sekam ke dalam dedak, sehingga kandungan nutirisi dedak padi perlu dicek ulang.

Hal yang paling mendasar adalah sikap peduli peneliti terhadap kebutuhan pakan dan pemenuhan gizi ternak yang menjadi tolak ukur keberhasilan dari peternak. Perkembangan usaha peternakan salah satunya ditentukan oleh kualitas pakan yang baik. Untuk itu, kandungan nutirisi dedak padi yang dihasilkan oleh mesin giling padi sangat penting dianalisis untuk mengetahui kualitasnya. Menurut Akbarillah et al. (2007) kualitas dedak padi dapat diukur dengan pengamatan fisik dan analisis komposisi kimiawi. Untuk mengetahui kandungan nutrisi dari dedak padi berupa serat kasar, bahan kering, dan protein kasar secara pasti dilakukan analisis proksimat. Menurut lqbal et al. (2020) usaha giling padi adalah gabungan kegiatan produksi, pasca panen, pengolahan dan pemasaran padi atau beras. Usaha ini sangat penting ketersediaan beras nasional dapat terpenuhi baik jumlah maupun kualitasnya. Ketersediaan yang memadai akan mendukung ketahanan pangan nasional. Usaha giling padi juga dapat berperan dalam meningkatkan pendapatan masyarakat. Tujuan semua suatu usaha ialah agar dapat memperoleh pendapatan yang tinggi. Akan tetapi sering sekali besarnya jumlah pendapatan yang didapat pelaku usaha belum sesuai dengan yang diharapkan. Namun pendapatan yang diperoleh usaha penggilingan padi belum tentu menjamin suatu usaha bisa dijalankan secara berkelanjutan. Jadi, sangat perlu untuk mengevaluasi tingkat atau jumlah pendapatan usaha penggilingan padi. Hal ini dapat menjadi tolak ukur masyarakat dalam mendirikan usaha penggilingan padi. Hipotesis dalam penelitian ini ialah Kandungan nutrisi dedak padi yang dihasilkan mesin giling yang memisahkan sekam dan dedak memiliki kandungan nutrisi lebih baik dari mesin giling yang tidak memisahkan sekam dan dedak.

\section{BAHAN DAN METODE \\ Waktu dan Tempat \\ Penelitian ini dilaksanakan di 9 desa dan 1 kelurahan di Kecamatan Umalulu Kabupaten Sumba Timur mulai dari bulan Juli sampai bulan Agustus di tahun 2021.}

\section{Alat dan Bahan}

Alat yang digunakan dalam penelitian adalah plastik sampel, kantung plastik, ball point, kuesioner, dan timbangan duduk. Pengumpulan data berupa sampel dedak padi dan pendapatan usaha penggilingan padi dilakukan dengan metode sensus dengan cara wawancara secara langsung dan obesrvasi terhadap pemilik/pelaku usaha yang masih 
aktif beroperasi. Penentuan sampel yang dianalisis proksimat menggunakan stratifikasi random sampling (acak) dengan sampel yang dianalisis sebanyak 6 sampel. Analisis proksimat dilakukan di Laboratorium Kimia Pakan Undana, Kupang, NTT. Analisis proksimat menggunakan prosedur AOAC (2016).

Data pada penelitian berasal dari dua sumber yaitu data primer dan data sekunder; Sumber data primer diperoleh melalui observasi yaitu pengambilan dedak padi di usaha penggilingan padi dan wawancara secara langsung. Sementara, data sekunder diperoleh dari instansi-instansi seperti Badan Pusat Statistik Kabupaten Sumba Timur, Pemerintah Kecamatan Umalulu, Pemerintah Desa serta bahan pustaka seperti jurnal, buku, dan pustaka-pustaka lainnya. Penelitian dilakukan selama dua bulan yaitu dari bulan Juli sampai Agustus 2021. Responden dipilih secara sengaja yaitu pelaku usaha penggilingan padi yang menetap dan aktif beroperasi di Kecamatan Umalulu. Menurut Momongan et al. (2019) cara menghitung pendapatan yaitu penerimaan dikurangi dengan biaya yang dikeluarkan, dengan rumus seperti yang dituliskan dibawah ini.

$$
\begin{aligned}
& \pi= \text { TR }- \text { TC } \\
& \text { Dimana: } \\
& \Pi=(\text { Keuntungan }) \\
& \text { TR }=(\text { Total Penerimaan }) \\
& \text { TC }=(\text { Total Biaya })
\end{aligned}
$$

\section{Analisis Data}

Semua data dianalisis deskriptif kauntitatif. Teknik analisis data untuk menghitung jumlah rata-rata pendapatan usaha menggunakan aplikasi MS Excel.

\section{HASIL DAN PEMBAHASAN}

\section{Karakteristik Responden}

Tabel 1 menyajikan data umur pemilik usaha penggilingan padi. Berdasarkan Tabel 1 dapat dilihat bahwa umur pemilik/pelaku usaha penggilingan padi 25-30 tahun sebanyak 8 orang dengan nilai presentase
$57 \%$, umur 31-40 tahun sebanyak 4 orang dengan jumlah persentase $29 \%$, dan umur $41>$ berjumlah 2 orang dengan presentase $14 \%$.

Tabel 1. Umur pemilik usaha penggilingan padi

\begin{tabular}{ccc}
\hline No & $\begin{array}{c}\text { Kelompok Umur } \\
\text { (tahun) }\end{array}$ & Jumlah \\
\hline 1 & $25-30$ & 8 \\
2 & $31-40$ & 4 \\
3 & $>41$ & 2 \\
\hline Jumlah & & 14
\end{tabular}

Tabel 1 menunjukkan bahwa responden pemilik usaha penggilingan padi di kecamatan Umalulu tergolong umur yang masih produktif, sehingga dengan umur yang produktif pemilik/pelaku usaha masih memiliki kemampuan fisik lebih baik dalam mengelola manajemen usaha yang ditekuni. Sesuai pendapat Aprianto et al. (2021) bahwa responden sebaiknya mempunyai fisik yang kuat dan tanggap terhadap inovasi yang dianjurkan. Hal tersebut sesuai dengan pernyataan Indrayani dan Andri (2018) yang menyatakan bahwa umur merupakan salah satu indikator kemampuan fisik seseorang. Menurut Hendrayani dan Febrina (2009) bahwa umur merupakan salah satu ciri yang selalu dimiliki dari tiap manusia yang mana umur berpengaruh terhadap fungsi biologis dan fisiologis dari individu tertentu

Tabel 2 menyajikan data jenis kelamin pemilik usaha penggilingan padi. Berdasarkan Tabel 2 dapat dilihat bahwa seluruh pemilik/pelaku usaha penggilingan padi berjenis kelamin laki-laki yaitu sebanyak 14 orang dengan presentase $100 \%$.

Tabel 2. Jenis kelamin pemilik usaha penggilingan padi

\begin{tabular}{clcc}
\hline No & $\begin{array}{l}\text { Jenis } \\
\text { Kelamin }\end{array}$ & $\begin{array}{c}\text { Jumlah } \\
\text { (orang) }\end{array}$ & $\begin{array}{c}\text { Persentase } \\
(\%)\end{array}$ \\
\hline 1 & Laki-laki & 14 & 100 \\
2 & Perempuan & 0 & 0 \\
\hline Jumlah & & 14 & 100 \\
\hline
\end{tabular}


Pada Tabel 2 menunjukkan bahwa usaha penggilingan padi membutuhkan tenaga dan fisik yang kuat. Jadi, usaha usaha penggilingan padi sangat membutuhkan kekuatan fisik lakilaki dibandingkan kekuatan fisik perempuan. Kegiatan seperti menghidupkan mesin, mengangkat padi untuk dimasukan kedalam mesin giling, dan memasukan beras/dedak ke dalam karung, membutuhkan tenaga yang kuat untuk mengoptimalkan pekerjaan tersebut. Pernyataan di atas sesuai dengan pernyataan Marina et al. (2021) yang menyatakan bahwa laki-laki memiliki peran sebagai kepala keluarga dan usaha ini sangat diperlukan tenaga lebih kuat dari tenaga Wanita.

Tabel 3. Tingkat pendidikan pemilik usaha penggilingan padi

\begin{tabular}{clcc}
\hline No & Pendidikan & $\begin{array}{c}\text { Jumlah } \\
\text { (orang) }\end{array}$ & $\begin{array}{c}\text { Persentase } \\
(\%)\end{array}$ \\
\hline 1 & SD & 2 & 14 \\
2 & SMP & 4 & 29 \\
3 & SMA & 8 & 57 \\
\hline Jumlah & & 14 & 100 \\
\hline
\end{tabular}

Berdasarkan Tabel 3 dapat dilihat bahwa tingkat pendidikan SD yaitu 2 orang dengan presentase $14 \%$, tingkat pendidikan SMP sebanyak 4 orang dengan presentase 29\%, dan tingkat pendidikan SMA sebanyak 8 orang dengan presentase $57 \%$.

Pada Tabel 3 menunjukkan bahwa tingkat pendidikan merupakan faktor yang harus disiapkan sebelum menjalankan suatu usaha. Hendrayani dan Febrina (2009) yang menyatakan bahwa ilmu pengetahuan, kemampuan, dan pola pikir dan produktifitas seseorang dapat di sesuaikan dengan tingkat pendidikan formal yang pernah pelajari, karena tingkat pendidikan yang rendah merupakan salah satu faktor penghalang untuk perkembangan individu. Semakin tinggi pendidikan individu tentunya akan semakin tinggi juga daya serap teknologi dan dapat dengan cepat dalam menerima ide terbaru dan kritik yang datang dari luar maupun dari dalam. Jadi, pendidikan dapat dijadikan sebagai ujung tombak dalam menentukan pola pikir dan tingkah laku manusia. Menurut Nurahman (2010) pembangunan pendidikan adalah salah satu program yang diperuntukan bagi pemerintah desa maupun masyarakat secara umum untuk meningkatkan kualitas sumber daya manusia yang tin

\section{Biaya Produksi}

Menurut Momongan et al. (2019) bahwa biaya usaha ialah seluruh biaya yang telah digunakan dalam membiayai keseluruhan kegiatan usaha tersebut. Biaya variabel merupakan biaya yang telah dikeluarkan yang sudah habis terpakai dalam satu kali masa produksi atau biaya yang tidak bisa dipakai secara terus menerus dalam proses produksi misalnya; penggunaan bahan bakar, pemeliharaan mesin, dan biaya tambahan (karung dan tali). Sementara biaya tetap adalah biaya yang dikeluarkan tanpa dipengaruhi oleh jumlah produksi, seperti biaya pajak, tenaga kerja, dan penyusutan mesin.

Berdasarkan Tabel 4 menunjukkan bahwa jumlah biaya variabel yang dikeluarkan usaha penggilingan padi di kecamatan Umalulu dalam 1 tahun adalah Rp 13.579.427. Biaya variabel terbesar yang dikeluarkan usaha penggilingan padi adalah biaya tambahan yaitu sebesar Rp 5.376.785, sisanya adalah biaya bbm sebesar Rp 3.892.285 dan biaya pemeliharaan mesin $\mathrm{Rp}$ 4.310.357. Jumlah biaya tetap yang dikeluarkan usaha penggilingan padi di Kecamatan Umalulu dalam 1 tahun adalah sebesar Rp 15.053.569. Biaya tetap terbesar yang dikeluarkan tiap usaha penggilingan padi adalah biaya penyusutan mesin yaitu sebesar $\mathrm{Rp}$ 11.357.142, sisanya adalah biaya pajak sebesar Rp 64.642 dan biaya tenaga kerja yaitu sebesar $\mathrm{Rp}$ 3.626.785. Total biaya yang dikeluarkan usaha penggilingan padi dalam 1 tahun adalah 28.632.996. Hasil penelitian diatas berbeda dengan Limbong et al. (2015) dengan judul penelitian "analisis kelayakan 
usaha penggiingan padi kecil" yang lokasi penelitiannya di Kecamatan Tanjung Morawa, Kabupaten Deli Serdang, Provinsi Sumatera Utara. Mereka menyimpulkan bahwa ratarata biaya produksi usaha penggilingan padi skala kecil di daerah penelitian adalah $\mathrm{Rp}$ 431.861.080 per tahun.

\section{Penerimaan}

Menurut Soekartawi (2003) penerimaan merupakan perkalian antara produksi yang diperoleh dengan harga jual. Perhitungan total penerimaan usaha penggilingan padi perlu dipisahkan antara analisis keseluruhan analisis parsial dan analisis keseluruhan usaha tani. Sumber penerimaan yang diperoleh usaha penggilingan padi di kecamatan Umalulu adalah hasil produksi berupa dedak padi yang dijual dalam kemasan karung $50 \mathrm{~kg}$.

Tabel 4. Biaya produksi usaha penggilingan padi

\begin{tabular}{|c|c|}
\hline Jenis Biaya & Jumlah (Rp) \\
\hline \multicolumn{2}{|l|}{ Biaya variabel } \\
\hline - $\quad B B M$ & 3.892 .285 \\
\hline - Pemeliharaan mesin & 4.310 .357 \\
\hline - Biaya tambahan & 5.376 .785 \\
\hline \multicolumn{2}{|l|}{ Biaya Tetap } \\
\hline - Pajak & 64.642 \\
\hline - Tenaga kerja & 3.626 .785 \\
\hline - Penyusutan mesin & 11.357.142 \\
\hline \multicolumn{2}{|l|}{ Jumlah biaya } \\
\hline - Biaya tetap & 15.053 .569 \\
\hline - $\quad$ Biaya variabel & 13.579 .427 \\
\hline - Jumlah & 28.632.996 \\
\hline
\end{tabular}

Dedak padi yang dihasilkan per tahun ratarata sebanyak 861 karung, harga jual per karung dedak padi sebesar Rp 125.000. Jadi total penerimaan setahun adalah sebesar $\mathrm{Rp}$ 107.625.000. Usaha penggilingan padi bisa menghasilkan kurang lebih 71-72 karung dedak padi dalam 1 bulan masa produksi Yang menjadi sumber pendapatan dari usaha penggilingan padi adalah penjualan hasil produksi berupa dedak padi. Hasil penelitian diatas berbeda dengan Mauliddar et al. (2013) dimana penerimaan yang didapatkan pada usaha penggilingan padi kecamatan Lubuk Pakam Kabupaten Deli Serdang berasal dari hasil penjualan beras dan dedak. Secara umum masyarakat di Kecamatan Umalulu yang memiliki usaha penggilingan padi memperoleh pendapatan dari hasil penjualan dedak. Menurut Darmawi (2011) jumlah yang diterima adalah hasil produksi yang dihasilkan oleh usaha, karena semakin besar produk yang dihasilkan maka semakin besar juga hasil yang diterima oleh pelaku usaha. Sebaliknya, apabila semakin kecil produk yang dihasilkan maka akan semakin kecil juga hasil yang diterima. Akan tetapi terkadang hasil yang diterima cukup besar belum tentu akan memperoleh keuntungan yang cukup besar.

\section{Pendapatan}

Pendapatan merupakan tujuan utama dari usaha dari suatu perusahaan yang berorientasi pada penghasilan, maka dari itu pendapatan mempunyai peranan yang sangat penting. Menurut Momongan et al. (2019) bahwa tingkat pendapatan diperoleh dari selisih antara total penerimaan dan total biaya produksi yang dikeluarkan.

Tabel 5. Jumlah pendapatan usaha penggilingan padi di Kecamatan Umalulu.

\begin{tabular}{ll}
\hline & Jumlah (Rp/tahun) \\
\hline Penerimaan & 107.625 .000 \\
Pengeluaran & 28.632 .996 \\
Jumlah Pendapatan (Rp) & 78.992 .004 \\
\hline
\end{tabular}

Berdasarkan Tabel 5 menunjukkan bahwa jumlah pendapatan usaha penggilingan padi di Kecamatan Umalulu disajikan pada Tabel 5. Berdasarkan Tabel 5 menunjukan bahwa usaha penggilingan padi (dari proses produksi sampai tahap penjualan dedak padi) menghasilkan penerimaan sebesar $\mathrm{Rp}$ 107.625.000 dalam satu tahun masa produksi. Tabel diatas diketahui bahwa biaya usaha penggilingan padi untuk satu tahun kegiatan usaha adalah sebesar Rp 28.632.996. Jadi, jumlah pendapatan dalam setahun sebesar Rp 78.992.004. Sumber pendapatan usaha 
penggilingan padi di Kecamatan Umalulu merupakan hasil produksi berupa dedak padi yang dijual kepada petani atau peternak dalam kemasan karung yang berukuran $50 \mathrm{~kg}$ dan dijual dengan harga Rp 125.000/karung.

\section{Kandungan Nutrisi Dedak Padi}

Tabel 6 menyajikan rata-rata kandungan nutrisi dedak padi di Kecamatan Umalulu. Terdapat dua tipe dedak, yaitu dedak tanpa sekam dan dedak terdapat sekam.

Tabel 6. Rata-rata kandungan nutrisi dedak padi di Kecamatan Umalulu

\begin{tabular}{lccc}
\hline Sampel & $\begin{array}{c}\text { Bahan } \\
\text { kering (\%) }\end{array}$ & $\begin{array}{c}\text { Protein } \\
\text { Kasar (\%) }\end{array}$ & $\begin{array}{c}\text { Serat } \\
\text { Kasar (\%) }\end{array}$ \\
\hline $\begin{array}{l}\text { Dedak } \\
\text { tanpa } \\
\text { sekam }\end{array}$ & 90,741 & 9,163 & 15,414 \\
$\begin{array}{l}\text { Dedak } \\
\text { terdapat } \\
\text { sekam }\end{array}$ & 89,836 & 9,831 & 14,020 \\
Rata-rata & 90,288 & 9,497 & 14,717 \\
\hline
\end{tabular}

\section{Bahan Kering}

Tabel 6 menunjukkan bahwa rata-rata bahan kering dedak padi tanpa sekam adalah $90,741 \%$ dan rata-rata dedak padi ada sekam adalah $89,836 \%$ dengan jumlah total bahan kering dedak padi adalah 90,288\%. Kandungan bahan kering yang tinggi menunjukkan bahwa padi ketika digiling telah kering. Menurut Akbarillah et al. (2007) bahwa jenis padi yang berbeda, memiliki kondisi fisik yang berbeda hal ini menyebabkan tingkat derajat rapuh, derajat rusak, dan kandungan air berubahubah. Berbeda dengan penelitian yang telah dilakukan oleh Dapawole \& Sudarma, (2020) mengatakan bahwa kandungan bahan kering dedak padi adalah 88,928\%. Dari hasil penelitian yang dilakukan kandungan bahan kering yang belum termasuk dalam Standar Nasional Indonesia mutu pakan. Sesuai dalam Standar Nasional Indonesia 01-3178, (2013) yang mengatakan bahwa dedak padi yang memiliki mutu yang baik adalah dedak padi yang memiliki bahan kering maksimal 13\%.

\section{Protein Kasar}

Tabel 6 bahwa rata-rata protein kasar dedak padi tanpa sekam adalah 9,163\% dan rata-rata dedak padi ada sekam adalah 9,831 dengan jumlah total protein kasar dedak padi adalah 9,497\%. Hasil penelitian menyimpulkan bahwa rata-rata kandungan protein kasar dedak padi belum memenuhi Standar Nasional Indonesia mutu pakan. Sesuai dalam Standar Nasional Indonesia (2013) bahwa dedak padi yang memiliki mutu yang baik adalah dedak padi yang memiliki protein kasar minimal 12\%. Secara umum protein sangat memiliki peran dalam pertumbuhan dan perkembangan segala jenis ternak. Menurut Scott et al. (2000) bahwa protein adalah salah satu nutrisi yang wajib menjadi perhatian sebelum meracik pakan, pemberian pakan pada ternak, sampai pada tahan untuk penilaian kualitas suatu bahan pakan. Secara umum protein sangat dibutuhkan oleh ternak untuk hidup pokok, proses tumbuh bulu dan perkembangan jaringan.

\section{Serat Kasar}

Tabel 6 menjelaskan bahwa rata-rata serat kasar dedak padi tanpa sekam adalah $15,414 \%$ dan rata-rata serat kasar dedak padi ada sekam adalah 14,020\% dengan jumlah total serat kasar adalah $14,717 \%$. Dari hasil penelitian dapat disimpulkan bahwa rata-rata serat kasar dedak padi belum yang memenuhi sesuai Standar Nasional Indonesia (2013) yang menyatakan bahwa dedak padi yang baik adalah dedak padi yang memiliki serat kasar maksimal $12 \%$. Penyebab kandungan serat kasar pada dedak padi tinggi adalah sekam yang dicampurkan ke dalam dedak. Hal tersebut sesuai dengan penyataan Hidayat et al. (2015) bahwa sekam digiling dan kemudian dicampurkan dedak padi. Hal ini yang menyebabkan kandungan serat kasar dedak padi semakin tinggi, karena sebagian besar sekam kandungannya adalah serat kasar. Adapun dampak dari tingginya serat kasar terhadap pertumbuhan ternak unggas adalah 
tidak optimal dikarenakan unggas sangat terbatas dalam mencerna serat kasar. Sesuai dalam penelitian Hidayat et al. (2015) yang menyatakan bahwa ternak unggas adalah salah satu ternak yang mempunyai keterbatasan dalam mencerna pakan yang memiliki serat kasar yang tinggi. Oleh karena itu serat kasar yang tinggi dapat menyebabkan dampak kurang baik terhadap pertumbuhan ternak unggas.

\section{KESIMPULAN}

Dapat ditarik kesimpulan bahwa jumlah pendapatan usaha penggilingan padi tergolong cukup besar. Jadi, usaha penggilingan padi merupakan salah satu jenis usaha yang dapat dijadikan sebagai sumber pendapatan. Kandungan nutrisi dedak padi yang dihasilkan oleh mesin giling yang memisahkan sekam dan yang tidak memisahkan sekam memiliki rata-rata kandungan nutrisi yang tidak terlalu berbeda jauh. Artinya, bahwa kandungan nutrisi dedak padi tidak hanya dipengaruhi oleh sistem kerja mesin dalam pemisahan dedak dan sekam, melainkan juga dapat dipengaruhi oleh faktor yang lain. Dedak padi di Kecamatan Umalulu tidak memenuhi standar mutu pakan. Jadi dedak padi di Kecamatan Umalulu kurang layak untuk diberikan pada ternak unggas.

\section{DAFTAR PUSTAKA}

Akbarillah, T., Hidayat, dan T. Khoiriyah. 2007. Kualitas Dedak dari Berbagai Varietas Padi di Bengkulu Utara. Jurnal Sain Peternakan Indonesia, 2(1): 36-41.

AOAC. 2012. Official Methods of Analysis of AOAC International, 19ed. Association of Analytical Chemist, Washintong, D. C.

Aprianto, A. Musram, dan S.Takdir. 2021. Analisis pendapatan usaha pemotongan ayam pedaging pada CV. Abu Chicken di Kecamatan Poasia Kota Kendari. Jurnal Peternakan, 5(2): 87-93.

Dapawole, R. R., dan I. M. A. Sudarma. 2020. Pengaruh pemberian level protein berbeda terhadap performans produksi itik umur 2-
10 minggu di Sumba Timur. Jurnal Sain Peternakan Indonesia, 15(3): 320-326. https://doi.org/10.31186/jspi.id.15.3.320326

Darmawi, D. 2011. Pendapatan Usaha Pemeliharaan Sapi Bali di Kabupaten Muaro Jambi. Jurnal Ilmiah Ilmu-IImu Peternakan , 14(1), 14-22.

Hendrayani, E., \& Febrina, D. (2009). Analisis

Faktor-Faktor Yang Mempengaruhi Motivasi Beternak Sapi di Desa Koto Benai Kecamatan Benai Kabupaten Kuantan Singingi. Jurnal Peternakan, 6(2), 53-62.

Hidayat, C., Sumiati, \& S Iskandar. (2015). Kualitas Fisik dan Kimiawi Dedak Padi yang Dijual di Toko Bahan Pakan di Sekitar Wilayah Bogor. Prosiding Seminar Nasional Teknologi Peternakan Dan Veteriner, 669674.

Indrayani, I., \& Andri. (2018). Faktor-faktor yang Mempengaruhi Pendapatan Usaha Ternak Sapi potong di Kecamatan Sitiung, Kabupaten Dharmasraya Infleuence Factors of Beef Cattle Farm's Income in Sitiung, Dharmasraya District. Jurnal Peternakan Indonesia, 20(3), 151-159.

Iqbal, M., M. A. Sadat, dan Arifin. 2020. Analisis pabrik penggilingan padi (Studi kasus penggilingan padi di Kelurahan Pabundukang Kecamatan Pangkaje'ne Kabupaten Pangkep. Jurnal Agribisnis, 12(2): 56-71.

Limbong, I., Darus, M. B., dan Emalisa. 2015. Analisis kelayakan usaha penggilingan padi skala kecil (Studi kasus: Kecamatan Tanjung Morawa, Kabupaten Deli Serdang, Provinsi Sumatera Utara). Journal of Agriculture and Agribusiness Socioeconomics, 4(12): 1-13.

Marina, I., L. Adam-Yuliandri, dan H. SriMulyani. 2021. Analisis sosial ekonomi daur ulang kotoran ternak sapi. Upaya mendukung pertanian berkelanjutan. Jurnal Ilmu Pertanian Dan Peternakan, 9(1): 44-48.

Mauliddar, A. N., M. B. Darus, dan L. Fauzia. 2013. Analisis kelayakan usaha 
penggilingan padi di Kecamatan Lubuk Pakam Kabupaten Deli Serdang. Journal of Agricultur and Agribisnis Socioeconomics, 2(4): 15-43.

Momongan, J. F., E. Ruauw, dan N. M. Benu,. 2019. Analisis keuntungan usaha penggilingan padi "Sederhana" di Desa Poopo Kecamatan Passi Timur Kabupaten Bolaang Mongondow. Agrirud, 1(1): 42-50. Munandar, A., W. M. Horhoruw, dan D. G. Joseph. 2020. Pengaruh pemberian dedak padi terhadap penampilan produksi ayam broiler. JPK, 4(1): 38-45.

Nurahman. 2010. Kajian faktor-faktor internal produktifitas usaha pengolahan produk agribisnis. Jurnal IImiah Departemen IImu Sosial Ekonomi IPB, 3(11):
Scott, M. L., Nesheim, dan R. J. Young. 2000. Nutritions of The Chickens (2nd ed.). Associates Ithaca.

Soekartawi. 2003. Teori Ekonomi Produksi. PT Raja Grafindo Persada.

Standar Nasional Indonesia. 2013. Dedak PadiBahan Pakan Ternak. www.bsn.go.id

Superianto, S., A. E. Harahap, dan A. Ali. (2018. Nilai nutrisi silase limbah sayur kol dengan penambahan dedak padi dan lama fermentasi yang berbeda. Jurnal Sain Peternakan Indonesia, 13(2): 172-188.

Valentino, I. K. H, T.I, Putri, dan K. Budaarsa. 2017. Performa dan koefisien cerna babi Bali yang diberi ransum mengandung dedak padi fermentasi. Jurnal Peternakan Tropika, 5(2), 324-335. 